Dunamis: Jurnal Teologi dan Pendidikan Kristiani

Volume 3, Nomor 1 (Oktober 2018)

ISSN 2541-3937 (print), 2541-3945 (online)

http://www.sttintheos.ac.id/e-journal/index.php/dunamis

\title{
Sudut Pandang Etika Keristen Menyikapi Pembangkangan Sipil (Civil Disobedience)
}

\author{
Sonny Eli Zaluchu \\ Sekolah Tinggi Teologi Baptis Indonesia Semarang \\ sonnyzaluchu@stbi.ac.id
}

\begin{abstract}
Disobedience to the government can be realized in two ways. First by peaceful means and second by fighting against using violence. This happens because the interests of the community are sacrificed and or fulfilled so that there is a crisis of relations between the community and the government. This article discusses the ins and outs of the occurrence of civil disobedience and the way it is addressed regarding Christian ethics. Even though Biblical justification is only in favor of the conditional opposition, the reality, the various forms, and practices of opposition to the government take place around us. Especially if we are in a critical situation such as repression or repressive action, our human nature immediately responds. So as Christians, of course, our response must be different. Biblical considerations are our only choice when in crisis and oppression. That's where we determine the attitude towards the government.
\end{abstract}

Keywords: disobedience; civil disobedience, government; ethics

\begin{abstract}
Abstrak
Pembangkangan terhadap pemerintah dapat diwujudkan dengan dua cara. Pertama dengan cara damai dan kedua dengan melawan menggunakan kekerasan. Hal ini terjadi karena kepentingan masyarakat dikorbankan dan atau terbaikan sehingga terjadi krisis hubungan antara masyarakat dengan pemerintah. Artikel ini membahas tentang seluk beluk terjadinya pembangkangan (civil disobedience) dan cara menyikapinya ditinjau dari sudut pandang etika Kristen. Sekalipun pembenaran Alkitabiah hanya memihak pada penentangan bersyarat, tetapi kenyataan-nya, berbagai bentuk dan praktek penentangan terhadap pemerintah, berlangsung disekeliling kita. Terutama jika kita berada di dalam sebuah situasi kritis seperti penindasan atau tindakan represif, natur manusiawi kita langsung memberikan responnya. Maka sebagai orang Kristen, tentu saja respon kita harus berbeda. Pertimbangan Alkitabiah menjadi satusatunya pilihan kita saat berada di dalam krisis dan penindasan. Dari sanalah kita menentukan sikap terhadap pemerintah.
\end{abstract}

Kata Kunci: pembangkangan; pembangkangan sipil; pemerintah; etika 


\section{PENDAHULUAN}

Studi kasus berikut ini menarik sebagai bahan kajian. Koran Tempo memberitakan penolakan masyarakat didukung oleh NGO terhadap sebuah pabrik di Porsea Sumatera Utara. ${ }^{1}$ Warga Porsea menyatakan protes

berkesinambungan kepada pemerintah karena mengijinkan perusahaan tersebut beroperasi kembali. ${ }^{2}$ Padahal, ditengarai pabrik tersebut menjadi salah satu sumber pencemaran lingkungan disekitarnya yang merugikan penduduk. Masyarakat di sana merasa bahwa pemerintah lebih membela kepentingan pemilik modal daripada memperhatikan kesejahteraan mereka sebagai penduduk asli dan juga kelestarian lingkungan hidup. Merasa tidak di dengarkan suaranya dan mendapat perlakuan represif dari aparat keamanan, masyarakat Porsea memilih melakukan beberapa hal sebagai berikut, (a) Mogok pergi ke sawah dan memilih melakukan aksi demo di lokasi pabrik. Hal ini dilakukan oleh ibu-ibu untuk mendukung para suami dan dalam menghadapi

\footnotetext{
${ }^{1}$ Tempo Interaktif, "NGO Di Sumatera Utara Tolak Beroperasinya Kembali Indorayon,” 21 Juli, 2003, https://nasional.tempo.co/read/2253/ngo-disumatera-utara-tolak-beroperasinya-kembaliindorayon.

${ }^{2}$ Tempo Interaktif, "Beroperasi Kembali, Toba Pulp Targetkan Produksi 180 Ribu Ton Per Tahun," 22 Juli, 2003, https://bisnis.tempo.co/read/2713/beroperasikembali-toba-pulp-targetkan-produksi-180-ributon-per-tahun.
}

tindakan represif dari aparat keamanan; (b) Para ibu di Porsea juga rela melanggar nilai, budaya, dan tradisi Batak dengan cara mewujudkan protes sambil beraksi membuka baju dan celana; (c) Masyarakat Porsea juga sepakat tidak pergi ke hari pekan atau hari pasar kecamatan yang biasanya digelar setiap Rabu. Mereka lebih memilih untuk membuka pasar-pasar kecil setiap minggu di masing-masing desa sebagai wahana memperjualkan hasil bumi; (d) Masyarakat Porsea juga memutuskan untuk tidak membayar segala macam bentuk pajak, mulai dari pajak bumi dan bangunan sampai pajak kendaraan bermotor. Menurut kesimpulan Silaen, fenomena protes masyarakat Porsea tersebut merupakan sebuah gerakan sosial (social movement) baru yang merindukan terjadinya perubahan dalam sistem, di dalam distribusi sumber daya atau pengambilan kebijakan serta komposisi para pemangku kekuasaan dalam masyarakat. Menurutnya, terjadi mobilisasi dari orang-orang yang merasa dikucilkan (left-out) oleh pemerintah dengan cara melakukan aksi pada level akar-rumput (grass-root). ${ }^{3}$

\footnotetext{
${ }^{3}$ Victor Silaen, "PERJUANGAN HAK-HAK SIPIL DALAM KONTEKS POLITIK LOKAL Studi Kasus Gerakan Perlawanan Rakyat Porsea Terhadap Indorayon," ejournal UKI (2018): 56-88, ejournal.uki.ac.id/index.php/sp/article/view/511/50 1 .
} 
Tindakan protes warga negara terhadap pemerintah dengan cara damai dan tanpa kekerasan seperti dilakukan oleh masyarakat Porsea tersebut menurut Ball adalah salah satu bentuk dan ciri perlawanan yang disebut pembangkangan sipil atau civil disobediance yang dilakukan oleh warga negara terhadap pemerintah. ${ }^{4}$ Selanjutnya menurut Ball, salah satu prinsip penting dalam pembangkangan sipil yaitu harus dilakukan tanpa kekerasan (nonviolent) dan lebih merupakan gabungan antara gerakan moral dan praktis. ${ }^{5}$ Dengan demikian disimpulkan bahwa pembangkangan sipil adalah salah satu bentuk perlawanan masyarakat terhadap pemerintah yang $\operatorname{sah}^{6}$

\footnotetext{
${ }^{4}$ Terrence Ball, "Civil Disobedience," International Encyclopedia of The Social Science (Macmillan Social Science Library, 1991).

${ }^{5}$ Terminologi Civil Disobedience (pembangkangan sipil), pertama kali populer dalam sebuah essay yang ditulis oleh Henry David Thoreau, seorang filsuf dan penulis asal Amerika. Mahatma Gandhi, tokoh kemerdekaan India, adalah salah satu tokoh yang terpengaruh oleh tulisan Thoreau ini. Prinsip Satyagraha (kebenaran dan keteguhan) dan Ahimsa (perlawanan tanpa kekerasan), adalah ajaran Gandhi yang sangat dipengaruhi gagasan Civil Disobedience. Martin Luther King Jr., tokoh gerakan hak-hak sipil di Amerika Serikat juga terpengaruh oleh gagasan Civil Disobedience tersebut.

(http://id.wikipedia.org/wiki/Pembangkangan_sipil (esai)

${ }^{6}$ E. Balibar, "Violence and Civility: On the Limits of Political Anthropology," Differences 20, no. 2-3 (2009): 9-35, http://differences.dukejournals.org/cgi/doi/10.1215/ 10407391-2009-002.
}

bahkan terhadap hukum yang telah ditetapkan oleh negara. ${ }^{7}$

Menyikapi kenyataan tersebut, muncul pertanyaan penting bagi kita, apakah pembangkangan terhadap pemerintah, entah dilakukan dengan kekerasaan atau tidak, dibolehkan dalam perspektif Kristiani? Namun, pertanyaan yang paling pokok adalah, bagaimana seharusnya sikap kita sebagai warga negara yang beriman kepada Yesus Kristus menghadapi pemerintahan yang berlaku tidak adil, semena-mena atau jahat terhadap rakyatnya? Apakah harus ditaati di dalam kepatuhan atau dilawan dengan dan atau tanpa kekerasan? Adakah tindakan pemerintah yang jahat tersebut layak diikuti atau ditentang? Bagaimana kita sebagai orang Kristen seharusnya menyikapi hal-hal semacam itu? Artikel ini disusun untuk memberikan satu landasan biblika dan teologis dalam perspektif etika dalam menjawab pertanyaan-pertanyan tersebut.

\section{METODOLOGI}

Penelitian ini menggunakan metode studi pustaka. Penulis menggali berbagai informasi tentang sikap masyarakat sipil, baik secara umum maupun masyarakat sipil Kristiani, melalui berbagai referensi

\footnotetext{
${ }^{7}$ William Smith, "Civil Disobedience and the Public Sphere," Journal of Political Philosophy 19, no. 2 (2011): 145-166.

https://doi.org/10.1111/j.1467-9760.2010.00365.x
} 
seperti artikel junal, konferensi, buku, maupun terbitan lainnya.

\section{ANALISIS DAN HASIL}

\section{Anatomi Kekerasan}

Salah satu cara paling ekstrim untuk menyatakan perlawanan terhadap pemerintah adalah penggunaan kekerasan. ${ }^{8}$ Dimana-mana kita menyaksikan demo yang berakhir kekerasan selalu membawa dampak buruk ketimbang hal-hal yang baik. ${ }^{9}$ Kekerasan dapat membawa korban baik manusia maupun kerusakan pada halhal material seperti gedung, kendaraan, dan barang-barang publik lainnya. ${ }^{10}$

Kenyataannya, tidak sedikit orang yang memilih menempuh jalan kekerasan untuk menyatakan sikap perlawanannya secara simbolik. ${ }^{11}$ Tentu saja, pemerintah sebagai pengendali tertinggi keamanan nasional akan melakukan berbagai macam upaya meredam perlawanan itu baik secara persuasif maupun represif. ${ }^{12}$

\footnotetext{
${ }^{8}$ Edward L. Glaeser and Cass R. Sunstein, $A$ Theory of Civil Disobedience, SSRN, 2015. https://doi.org/10.2139/ssrn.2625273

${ }^{9}$ B Susantyo, "Memahami Perilaku Agresif: Sebuah Tinjauan Konseptual," Jurnal 16, no. 03 (2011): 189-202, http://puslit.depsos.go.id/upload/post/files/350d40e dc66e2a381a752512210a8d6d.pdf.

${ }^{10}$ Daniel Mider, "The Anatomy of Violence: A Study of the Literature," Aggression and Violent Behavior, 2013. DOI: 10.1016/j.avb.2013.07.021 ${ }^{11}$ Syahril Syahril, "Arena Produksi Kultural Dan Kekerasan Simbolik,” Jurnali Ilmiah Peuradeun 2, no. 1 (2014).

${ }^{12}$ N. Rose, "Government and Control," British Journal of Criminology 40, no. 2 (2000): 321-339, https://academic.oup.com/bjc/article-
}

Akan tetapi, dilihat di dalam persepektif kekristenan, tindakan kekerasan di dalam level manapun, sejatinya berlawanan dengan ajaran Yesus tentang kasih. ${ }^{13}$ Lihat misalnya kesimpulan Yesus tentang hukum Taurat yang mengatakan: Jawab Yesus kepadanya: "Kasihilah Tuhan, Allahmu, dengan segenap hatimu dan dengan segenap jiwamu dan dengan segenap akal budimu. Itulah hukum yang terutama dan yang pertama. Dan hukum yang kedua, yang sama dengan itu, ialah: Kasihilah sesamamu manusia seperti dirimu sendiri. Pada kedua hukum inilah tergantung seluruh hukum Taurat dan kitab para nabi" (Matius 22:37-40). Pernyataan itu tentu saja mengejutkan murid-muridNya dan orang-orang Yahudi yang mendengarnya karena eskalasi kekerasan melawan penjajah Romawi yang tiran sudah mulai terlihat dimana-mana di masa pelayanan Yesus di dunia. Kelompok Zelot misalnya, memegang teguh prinsip kekerasan di dalam mengusir kekuasaan Romawi di Palestina. ${ }^{14}$ Perlawanan menggunakan kekerasan sudah muncul di

lookup/doi/10.1093/bjc/40.2.321. DOI:

10.1093/bjc/40.2.321

${ }^{13}$ Max L. Stackhouse, "The Christian Ethic of Love: A Dialogical Response," Journal of Religious Ethics, 2007. DOI: 10.1111/j.14679795.2007.00328.x

${ }^{14}$ David F. Hinson, Sejarah Israel Pada Zaman Alkitab, 10th ed. (Jakarta: BPK Gunung Mulia, 2014), 271. 
zaman Yesus. Realitas tersebut bertolak belakang dengan anjuran Yesus tentang mengasihi musuh. Dengan kata lain, disimpulkan, mengatakan bahwa kekerasan adalah sebuah ekspresi mengasihi, adalah cara pandang yang sama sekali bertentangan dengan apa yang Yesus ajarkan. Menyatakan sikap dengan jalan kekerasan dengan sendirinya menyalahi hukum Yesus tentang kasih. ${ }^{15}$

Implikasi praktis dari kesimpulan tersebut sangat luas. Orang Kristen tidak terpanggil untuk melakukan kekerasan kepada pemerintah bahkan juga tidak terpanggil untuk mengobarkan semangat kekerasan sebagai wujud penyataan sikap, penolakan atau gerakan sosial, dimanapun berada. Namun demikian, disisi yang lain, berkembangnya kekerasan sebagai bagian dari budaya gerakan sosial bahkan atas nama agama ${ }^{16}$, terus tumbuh seolah anjuran Yesus tentang mengasihi, tidak manjur di dalam tataran perilaku.

Agustinus, salah seorang pemikir Kristiani yang terkenal, dalam bukunya The City of God menjadi salah seorang tokoh yang melegalkan dan menganjurkan orang untuk melakukan praktek kekerasan.

\footnotetext{
${ }^{15}$ Richard Bartlett Gregg, "The Power of Nonviolence," Schocken paperbacks, SB136 (1966): $192 \mathrm{p}$.

${ }^{16}$ M.D. Litonjua, "Religious Zealotry and Political Violence in Christianity and Islam," International Review of Modern Sociology 35, no. 2 (2009): 307331, https://www.jstor.org/stable/41421360.
}

Agustinus berpendapat bahwa orang-orang benar boleh terpaksa melawan orang-orang jahat. Terutama di dalam konteks peperangan untuk mencari perdamaian, kekerasan dapat dilakukan untuk tujuan penaklukan. ${ }^{17}$ Tetapi Agustinus tidak menyadari bahwa kasih sebagai salah satu prinsip dasar dari kekristenan justru menentang kekerasan. Terlihat di dalam ajaran Yesus di bukit, siklus kekerasan di kalangan masyarakat Yahudi pada waktu itu dipatahkan dengan pengajaran yang justru menantang para pendengarnya untuk tidak membalas dendam atas luka-luka yang mereka derita. Tuhan Yesus berkata, "Kamu telah mendengar firman: Mata ganti mata dan gigi ganti gigi. Tetapi Aku berkata kepadamu: Janganlah kamu melawan orang yang berbuat jahat kepadamu, melainkan siapapun yang menampar pipi kananmu, berilah juga kepadanya pipi kirimu. Dan kepada orang yang hendak mengadukan engkau karena mengingini bajumu, serahkanlah juga jubahmu. Dan siapapun yang memaksa engkau berjalan sejauh satu mil, berjalanlah bersama dia sejauh dua mil" (Matius 5:38-41).

Yesus mengambil studi kasus dari pengalaman bangsa Yahudi yang pada masa itu berada di dalam penjajahan

\footnotetext{
${ }^{17}$ Leo D. Lefebure, Pernyataan Allah, Agama Dan Kekerasan (Jakarta: BPK Gunung Mulia, 2006).
} 
romawi yang tiran. Sekalipun pemerintah tiran dan para prajurit romawi bertindak semena-mena, Yesus sama sekali tidak mengajurkan praktek kekerasan untuk menghadapi situasi tersebut. Salah satu tindakan populer prajurit Romawi pada waktu itu adalah hak para tentara untuk memaksa setiap orang Yahudi yang berpapasan dengan mereka untuk memikul peralatan perang sejauh satu mil. ${ }^{18} \mathrm{Di}$ bagian lain Yesus menegaskan kembali akan sikap anti kekerasan tersebut, "Kamu telah mendengar firman: Kasihilah sesamamu manusia dan bencilah musuhmu. Tetapi Aku berkata kepadamu: Kasihilah musuhmu dan berdoalah bagi mereka yang menganiaya kamu. Karena dengan demikianlah kamu menjadi anakanak Bapamu yang di sorga, yang menerbitkan matahari bagi orang yang jahat dan orang yang baik dan menurunkan hujan bagi orang yang benar dan orang yang tidak benar" (Matius 5:43-45).

Pengajaran Tuhan Yesus tersebut sekaligus menekankan kepada kita bahwa cakupan istilah 'sesama' di dalam mempraktekkan kasih diperluas, bukan hanya kepada orang yang telah berbuat

\footnotetext{
${ }^{18}$ Disebut dengan hukum satu mil atau angeria (million atau mil), hak yang diberikan kepada setiap prajurit romawi untuk memaksa seseorang membawa senjata mereka sejauh satu mil. Ada orang-orang Yahudi yang terpaksa melakukan itu dan bahkan yang lari menghindari saat hendak berpapasan dengan rombongan prajurit Romawi.
}

baik, tetapi juga kepada musuh atau orang yang melakukan kejahatan atas kita. Inilah yang menjadi standard etika di dalam menyikapi perilaku kekerasan yang membudaya disekeliling kita. Berangkat dari pengajaran Yesus tersebut menjadi jelas bagi kita bahwa apapun bentuk penggunaan kekerasan terhadap pemerintah merupakan suatu tindakan yang tidak dianjurkan secara kristiani.

\section{Taat Sepenuhnya}

Namun demikian, terdapat juga kelompok ekstrim yang menentang kekerasan dan menekankan ketaatan. Kelompok ini memandang bahwa pemerintahan di dunia ini adalah berasal dari Allah sehingga sekalipun pemerintahan tersebut korup atau melakukan kejahatan bahwa kesewenangwenangan, sebagai warga negara yang baik, pemerintahan harus tetap ditaati sepenuhnya. Dalam pendangan kelompok ini, pembangkangan terhadap pemerintah, apalagi jika diekspresikan dalam bentuk kekerasan, tidak dibenarkan.

Dalam salah satu bagian bukunya berjudul Etika Kristen, Geisler menamakan kelompok ini dengan sebutan Radikal Patriotisme, sebab mereka menganut faham yang mengharuskan tunduk sepenuhnya kepada pemerintah. Menurutnya, ketaatan terhadap pemerintah 
tersebut menjadi refleksi ketaatan terhadap Allah sendiri. Salah satu argumentasi yang dipergunakan oleh kelompok ini di dalam membela pandangan mereka adalah Roma 13:2 yang mengatakan bahwa "barang siapa yang melawan pemerintah, ia melawan ketetapan Allah”. Itu kelompok ini memegang teguh nilai bahwa ketidaktaatan atau pembangkangan terhadap pemerintah tidak pernah dibenarkan. ${ }^{19}$ Landasan sikap ini adalah surat Rasul Paulus yang mengatakan tidak ada pemerintahan yang tidak berasal dari Allah. "Tiap-tiap orang harus takluk kepada pemerintah yang di atasnya, sebab tidak ada pemerintah, yang tidak berasal dari Allah; dan pemerintah-pemerintah yang ada, ditetapkan oleh Allah. Sebab itu barangsiapa melawan pemerintah, ia melawan ketetapan Allah dan siapa yang melakukannya, akan mendatangkan hukuman atas dirinya" (Roma 13:1-2).

Berdasarkan pemahaman terhadap ayat tersebut, kelompok Radikal Patriotisme memandang bahwa pemerintah itu berasal dari Allah dan ditetapkan oleh Allah. Oleh sebab itu, pemerintah harus dihormati dan dihargai sebab dengan melakukannya, hal itu sama dengan menghormati dan menghargai Allah. Bahkan kelompok ini juga memakai satu

\footnotetext{
${ }^{19}$ Norman Geisler, Etika Kristen - Pilihan Dan Isu (Malang: Literatur SAAT, 2007), 307.
}

bagian di dalam surat Paulus kepada Titus. "Ingatkanlah mereka supaya mereka tunduk pada pemerintah dan orang-orang yang berkuasa, taat dan siap untuk melakukan setiap pekerjaan yang baik" (Titus 3:1). Melalui pemahaman terhadap ayat tersebut, kelompok ini mengembangkan doktrin yang sangat kuat bahwa ketaatn terhadap pemerintah diawali oleh sikap penundukan diri.

Pemahaman tersebut bukan tanpa persoalan. Salah satunya adalah mengenai batasan ketundukan dan ketaatan terhadap pemerintah. Persoalannya akan semakin rumit jika sikap tunduk dan taat itu harus diterapkan di dalam pemerintahan yang tiran, korup atau jahat seperti yang terjadi di zaman Yesus; Romawi memaksakan kehendak di segal aspek hidup masyarakat Yahudi.

Geisler mengomentari bahwa pemahaman terhadap ayat-ayat tersebut di atas perlu diletakkan di dalam konteks yang tepat. Memang betul bahwa Allah yang melantik pemerintah tetapi harus juga disadari bahwa kejahatan yang dilakukan oleh pemerintah, sesungguhnya tidak berasal dari Allah bahkan tidak diperintahkan oleh Allah. Geisler berpendapat, tidak ada petunjuk di dalam Alkitab bahwa Allah senang terhadap pemerintahan yang jahat. Memang Allah yang menunjuk pemerintahan tetapi Ia 
tidak menyetujui kejahatan-kejahatannya ${ }^{20}$. Dari sinilah, batasan tentang ketundukan dan ketaatan dapat terbentuk. Sekalipun kelompok ini menganggapnya sebagai hal yang mutlak dan sepenuhnya, Geisler berpendapat lain. Pemerintah memang harus ditaati tetapi ketaatan itu punya batas dan tidak bersifat total. Dalam perspektif Kristiani, acuan ketaatan itu adalah Allah sendiri dan hukum-hukumNya. Selama pemerintahan itu menempatkan dirinya di bawah Allah dan tidak mengambil tempat Allah, maka orang Kristen dianjurkan taat kepada pemerintahan semacam itu.

Demikian halnya jika berlaku sebaliknya ${ }^{21}$. Salah satu studi kasus menarik adalah saat Petrus diperintahkan oleh pemerintah setempat untuk tidak memberitakan Injil. Kepada mereka, Petrus menyatakan sikapnya. "Silakan kamu putuskan sendiri manakah yang benar di hadapan Allah: taat kepada kamu atau taat kepada Allah" (Kisah Para Rasul 4:19).

Perkataan Petrus yang ditujukan kepada pemimpin-pemimpin Yahudi, tuatua dan ahli Taurat itu menjelaskan bagaimana Petrus memposisikan diri dalam konteks sub-ordinasi yang terbatas. Pilihan yang diajukan Petrus menjelaskan sikapnya bahwa dirinya memilih taat kepada Tuhan daripada manusia. Inilah

${ }^{20}$ Ibid., 308.

${ }^{21}$ Ibid. yang menjadi teladan etika di dalam persoalan yang sama dalam konteks modern. Selama pemerintahan itu tidak mengambil posisi Allah, maka kita perlu menaatinya. Dimensi lain dari persoalan ini adalah menempatkan ketaatan pada pemerintah tanpa perlu menaati kejahatankejahatannya. Untuk kasus ini Geisler berpendapat, orang-orang Kristen dapat menaati pemerintah yang mengizinkan kejahatan, tetapi tidak kepada pemerintah yang memerintahkan mereka untuk berbuat jahat. ${ }^{22}$ Pemerintah yang mengizinkan kejahatan dengan pemerintah yang menganjurkan untuk berbuat jahat, adalah dua kondisi yang berbeda. Seperti kasus yang pernah terjadi di negara Afrika yang dipimpin oleh salah seorang diktatornya yang terkenal jahat dan bengis yakni Idi Amin, sikap masyarakat untuk tetap membayar pajak, membayar retribusi dan patuh terhadap hukum yang dipimpin oleh pemerintahan yang jahat, adalah sebuah keteladanan. Dan memang demikianlah seharusnya, sama seperti ketaatan warga negara atas hukum yang berlaku di Korea Utara ataupun pada waktu Iraq dipimpin oleh Saddam Husein.

Kasusnya menjadi berbeda ketika pemerintah yang jahat itu, juga menganjurkan warga negaranya untuk melakukan kejahatan. Dalam hal inilah,

${ }^{22}$ Ibid. 
mempertimbangkan untuk tidak menaati pemerintah adalah tindakan yang sangat penting. Satu kasus di dalam PL menegaskan hal ini. Ketika Firaun meminta bidan-bidan Mesir untuk membunuh bayi-bayi yang tidak bersalah dari perempuan Ibrani, para bidan ini memilih untuk tidak menaati anjuran yang jahat tersebut, sekalipun di saat yang sama, mereka adalah warga negara Mesir yang berada di dalam ketentuan hukum negaranya dan pemerintahnya. Peristiwa itu dicatat di dalam Kitab Keluaran, "Apabila kamu menolong perempuan Ibrani pada waktu bersalin, kamu harus memperhatikan waktu anak itu lahir: jika anak laki-laki, kamu harus membunuhnya, tetapi jika anak perempuan, bolehlah ia hidup. Tetapi bidan-bidan itu takut akan Allah dan tidak melakukan seperti yang dikatakan raja Mesir kepada mereka, dan membiarkan bayi-bayi itu hidup" (Keluaran 1:16-17).

\section{Dua Kelompok Ekstrim}

Dengan demikian ada sebuah batasan yang jelas kapan harus tunduk dan taat kepada pemerintah dan kapan harus tidak. Geisler menamakan kelompok yang mempertimbangkan alasan-alasan logis di dalam konteks ketaatan kepada pemerintahan sebagai Submisionisme
Alkitabiah $^{23}$. Kelompok ini menegaskan bahwa ada saat-saat dimana orang Kristen harus taat dan adapula saat-saat dimana perlu terlibat dalam ketidaktaatan terhadap pemerintah. Persoalan yang muncul dari paham ini adalah tentang garis batas yang menjadi patokan, kapan harus taat dan kapan harus tidak taat. Geisler menemukan ada dua sikap yang menjadi alasan ketidaktaaan. Yang pertama adalah saat pemerintah mengajarkan hukum yang bertentangan dengan firman Allah, dan yang kedua adalah saat pemerintah memerintahkan orang Kristen melakukan kejahatan.

Kelompok yang pertama adalah kelompok yang membangkang pemerintah saat pemerintah menetapkan hukumhukum yang tidak alkitabiah. Francis Schaeffer adalah seorang tokoh yang mendukung ide tersebut melalui karyanya yang berjudul $A$ Christian Manifesto.

Schaeffer berpendapat bahwa pemerintah tidaklah memiliki kekuasaan yang mutlak sehingga bisa berlaku sewenang-wenang terhadap warga negaranya. Ketidakmutlakkan ini berlangsung karena pemerintah berada di bawah hukum dan bukan berada diatasnya ${ }^{24}$. Hukum yang sebenarnya adalah hukum Allah sehingga pemerintah harus tunduk pada hukum

\footnotetext{
${ }^{23}$ Ibid., 309.

${ }^{24}$ Francis A. Schaeffer, A Christian Manifesto (Westchester: Crossway, 1981), 100.
} 
Allah. Pemerintah bukanlah hukum Allah tetapi berada di bawah hukum Allah. Atas dasar asumsi inilah ketaatan Kristen terhadap pemerintah hanya berlangsung selama pemerintah berlaku sesuai hukum Allah $^{25}$. Bahkan menurut Schaffer, kapan saja sebuah pemerintah memerintah bertentangan dengan hukum Allah, maka pemerintah tersebut memerintah dengan kejam. Untuk menghadapi pemerintah semacam itu diperlukan protes dan kekuatan. Warga negara harus memprotes hukum-hukum yang bertentangan dengan Firman Allah. Jika gagal, maka kekuatan mungkin diperlukan. ${ }^{26}$ Kekuatan menurut Schaeffer diperlukan untuk melawan suatu negara yang menindas, jika perlu kekuatan digunakan untuk membela diri. ${ }^{27}$

Kelompok kedua adalah kelompok yang membangkang pemerintah saat pemerintah menganjurkan atau memaksa untuk berbuat jahat. Menurut Geisler, terdapat sejumlah daftar yang menjadi identifikasi ketidaktaatan yakni (a) ketika pemerintah memerintahkan kejahatan; (b) ketika pemerintah memaksakan tindakantindakan yang jahat; (c) ketika pemerintah meniadakan kebebasan; dan (d) ketika pemerintah menindas agama. ${ }^{28}$ Beberapa

\footnotetext{
${ }^{25}$ Geisler, Etika Kristen - Pilihan Dan Isu, 310.

${ }^{26}$ Ibid.

${ }^{27}$ Schaeffer, A Christian Manifesto, 104.

${ }^{28}$ Geisler, Etika Kristen - Pilihan Dan Isu, 313.
}

contoh di dalam Alkitab mengenai hal ini antara lain $^{29}$ :

- Penolakan para bidan Mesir untuk membunuh bayi-bayi Ibrani yang tidak bersalah (Keluaran 1:15-21)

- Penolakan atas perintah Firaun untuk tidak menyembah Allah (Keluaran $5: 1)$

- Penolakan nabi-nabi yang tidak mau dibunuh oleh Izebel (1 Raja-raja 18:4)

- Penolakan Daniel dkk untuk menyembah patung (Daniel 3:18)

- Penolakan Daniel untuk berdoa kepada raja dan bukan kepada Allah (Daniel 6:8-11)

- Penolakan Petrus untuk berhenti mengabarkan Injil (Kisah Para Rasul $4: 18-21)$

Kedua pandangan tersebut di atas bersama-sama menerima pemberontakan dan penolakan sebagai langkah yang harus dilakukan untuk menyatakan ketidaktaatan. Pada bagian awal makalah ini sudah dikemukakan bahwa ketidaktaatan dengan langkah pemberontakan, cuma akan melahirkan krisis. Salah satu contohnya adalah keterlibatan Reinhold Niebuhr, seorang teolog yang menganut aliran neoortodoks di dalam menyikapi ketidakadilan sosial yang diterima para buruh dari pemilik modal. Krisis tersebut menyeret

${ }^{29}$ Ibid., 313-314. 
Niebuhr untuk terlibat di dalam penentangan terbuka terhadap para pemilik modal. ${ }^{30}$ Tentu saja hal tersebut tidak memiliki dasar firman yang kuat. Dalam perspektif Alkitab, diusulkan oleh Geisler, ketidaktaatan kepada pemerintah yang dibenarkan, seharusnya perlawanan tanpa kekerasan, bukannya pemberontakan yang hebat. Geisler mencontohkan, penolakan para bidan Mesir untuk membunuh bayibayi Ibrani, tidak menuntun mereka untuk memberontak terhadap pemerintahan Mesir yang jahat itu. ${ }^{31}$

\section{KESIMPULAN}

Dengan demikian kita simpulkan bahwa penentangan terhadap pemerintah haruslah melalui pertimbanganpertimbangan tertentu dan tidak selamanya dianggap sebagai langkah yang tidak benar. Apalagi jika penentangan tersebut dilakukan atas nama agama tanpa melalui pertimbangan etis, sangat tidak relevan dengan nilai-nilai yang diperjuangkan oleh agama itu sendiri. ${ }^{32}$ Diakui, terdapat kondisi-kondisi tertentu menjadi sebuah pra-syarat untuk mengambil sikap terhadap pemerintah dan kebijakannya. Acuan utamanya adalah hukum-hukum Allah

\footnotetext{
${ }^{30}$ Paul Enns, The Moody Handbook of Theology Jilid 1 (Malang: Literatur SAAT, 2004), 218.

${ }^{31}$ Ibid., 316.

${ }^{32}$ Ahmad Isnaini, "Kekerasan Atas Nama Agama," Kalam 8, no. 2 (2017): 213, http://ejournal.radenintan.ac.id/index.php/KALAM/ article/view/221. DOI: 10.24042/klm.v8i2.221
}

sendiri yang melarang manusia melakukan kekerasan dan kejahatan.

Maka kembali kepada pertanyaan mendasar, apakah yang harus dilakukan saat berhadapan dengan pemerintah yang jahat dan tiran? Bukan saja menjadi teladan yang baik, tetapi kita juga perlu berdoa bagi pemerintahan manapun supaya mereka membangun pemerintahan, tata cara, perilaku dan hukum yang takut akan Tuhan. Jika hal itu masih terus terjadi, seperti diusulkan oleh Geisler, maka pemberontakan bukanlah solusi yang dianjurkan. Pilihannya ada tiga yakni (a) tidak menaati perintah-perintah yang opresif dengan menjunjung tinggi semangat yang takut akan Allah (lebih takut Allah daripada manusia); (b) menghindari kekerasan yang ditujukan kepada kita; dan (c) menghadapinya dengan sikap menanggung penderitaan bersama Kristus. $^{33}$

Dalam perspektif etika Kristiani, tindakan civil disobedience, seperti dilakukan oleh masyarakat Porsea menghadapi pemerintah, adalah salah satu keputusan etis dan menjadi salah satu pertimbangan kita di dalam bersikap menghadapi kasus-kasus serupa di masa yang akan datang. ${ }^{34}$ Etika menganjurkan

\footnotetext{
${ }^{33}$ Enns, The Moody Handbook of Theology Jilid 1, 323-324.

${ }^{34}$ Bedau, Hugo Adam. Civil Disobedience in Focus. Routledge Philosophers in Focus Series,
} 
kita untuk taat kepada pemerintah selama pemerintahan itu tidak melawan hukum Allah dan selama pemerintah itu tidak menganjurkan kita melakukan kejahatan atau menindas rakyatnya.

\section{DAFTAR PUSTAKA}

Balibar, E. "Violence and Civility: On the Limits of Political Anthropology." Differences 20, no. 2-3 (2009): 9-35. http://differences.dukejournals.org/cgi /doi/10.1215/10407391-2009-002.

Ball, Terrence. "Civil Disobedience." International Encyclopedia of The Social Science. Macmillan Social Science Library, 1991.

Bedau, Hugo Adam. Civil Disobedience in Focus. Routledge Philosophers in Focus Series, 1991. http://www.loc.gov/catdir/enhanceme nts/fy0648/90041094-d.html.

Enns, Paul. The Moody Handbook of Theology Jilid 1. Malang: Literatur SAAT, 2004.

Geisler, Norman. Etika Kristen - Pilihan Dan Isu. Malang: Literatur SAAT, 2007.

Glaeser, Edward L., and Cass R. Sunstein. A Theory of Civil Disobedience. SSRN, 2015.

Gregg, Richard Bartlett. "The Power of Nonviolence." Schocken paperbacks, SB136 (1966): $192 \mathrm{p}$.

Hinson, David F. Sejarah Israel Pada Zaman Alkitab. 10th ed. Jakarta: BPK Gunung Mulia, 2014.

Isnaini, Ahmad. "Kekerasan Atas Nama Agama." Kalam 8, no. 2 (2017): 213. http://ejournal.radenintan.ac.id/index.

1991. Routledge.

http://www.loc.gov/catdir/enhancements/fy0648/90 041094-d.html
php/KALAM/article/view/221.

Lefebure, Leo D. Pernyataan Allah, Agama Dan Kekerasan. Jakarta: BPK Gunung Mulia, 2006.

Litonjua, M.D. "Religious Zealotry and Political Violence in Christianity and Islam." International Review of Modern Sociology 35, no. 2 (2009): 307-331. https://www.jstor.org/stable/4142136 0 .

Mider, Daniel. "The Anatomy of Violence: A Study of the Literature." Aggression and Violent Behavior, 2013.

Rose, N. "Government and Control." British Journal of Criminology 40, no. 2 (2000): 321-339. https://academic.oup.com/bjc/articlelookup/doi/10.1093/bjc/40.2.321.

Schaeffer, Francis A. A Christian Manifesto. Westchester: Crossway, 1981.

Silaen, Victor. "PERJUANGAN HAKHAK SIPIL DALAM KONTEKS POLITIK LOKAL Studi Kasus Gerakan Perlawanan Rakyat Porsea Terhadap Indorayon." ejournal UKI (2018): 56-88. ejournal.uki.ac.id/index.php/sp/article /view/511/501.

Smith, William. "Civil Disobedience and the Public Sphere." Journal of Political Philosophy 19, no. 2 (2011): 145-166.

Stackhouse, Max L. "The Christian Ethic of Love: A Dialogical Response." Journal of Religious Ethics, 2007.

Susantyo, B. "Memahami Perilaku Agresif: Sebuah Tinjauan Konseptual." Jurnal 16, no. 03 (2011): 189-202. http://puslit.depsos.go.id/upload/post/ files/350d40edc66e2a381a752512210 a8d6d.pdf. 
Syahril, Syahril. "Arena Produksi Kultural Dan Kekerasan Simbolik." Jurnali Ilmiah Peuradeun 2, no. 1 (2014).

Tempo Interaktif. "Beroperasi Kembali, Toba Pulp Targetkan Produksi 180 Ribu Ton Per Tahun." 22 Juli, 2003. https://bisnis.tempo.co/read/2713/bero perasi-kembali-toba-pulp-targetkan- produksi-180-ribu-ton-per-tahun. . "NGO Di Sumatera Utara Tolak Beroperasinya Kembali Indorayon." 21 Juli, 2003.

https://nasional.tempo.co/read/2253/n go-di-sumatera-utara-tolakberoperasinya-kembali-indorayon. 